\title{
The amelioration of phagocytic ability in microglial cells by curcumin through the inhibition of EMF-induced pro-inflammatory responses
}

\author{
Gen-Lin He ${ }^{1,2+}$, Yong Liu ${ }^{3+}$, Min Li ${ }^{1}$, Chun-Hai Chen ${ }^{1}$, Peng Gao', Zheng-Ping Yu ${ }^{1}$ and Xue-Sen Yang ${ }^{1,2^{*}}$
}

\begin{abstract}
Background: Insufficient clearance by microglial cells, prevalent in several neurological conditions and diseases, is intricately intertwined with MFG-E8 expression and inflammatory responses. Electromagnetic field (EMF) exposure can elicit the pro-inflammatory activation and may also trigger an alteration of the clearance function in microglial cells. Curcumin has important roles in the anti-inflammatory and phagocytic process. Here, we evaluated the ability of curcumin to ameliorate the phagocytic ability of EMF-exposed microglial cells (N9 cells) and documented relative pathways.
\end{abstract}

Methods: N9 cells were pretreated with or without recombinant murine MFG-E8 (rmMFG-E8), curcumin and an antibody of toll-like receptor 4 (anti-TLR4), and subsequently treated with EMF or a sham exposure. Their phagocytic ability was evaluated using phosphatidylserine-containing fluorescent bioparticles. The pro-inflammatory activation of microglia was assessed via CD11b immunoreactivity and the production of tumor necrosis factor-a (TNF-a), interleukin-6 (IL-6), interleukin-1 $\beta(\mathrm{IL}-1 \beta)$ and nitric oxide (NO) via the enzyme-linked immunosorbent assay or the Griess test. We evaluated the ability of curcumin to ameliorate the phagocytic ability of EMF-exposed N9 cells, including checking the expression of MFG-E8, $a_{v} \beta_{3}$ integrin, TLR4, nuclear factor-KB (NF-KB) and signal transducer and activator of transcription 3 (STAT3) using Western blotting.

Results: EMF exposure dramatically enhanced the expression of CD11b and depressed the phagocytic ability of N9 cells. rmMFG-E8 could clearly ameliorate the phagocytic ability of N9 cells after EMF exposure. We also found that EMF exposure significantly increased the secretion of pro-inflammatory cytokines (TNF-a, IL- 6 and IL-1 $\beta$ ) and the production of $\mathrm{NO}$; however, these increases were efficiently chilled by the addition of curcumin to the culture medium. This reduction led to the amelioration of the phagocytic ability of EMF-exposed N9 cells. Western blot analysis revealed that curcumin and naloxone restored the expression of MFG-E8 but had no effect on TLR4 and cytosolic STAT3. Moreover, curcumin significantly reduced the expression of NF-kB p65 in nuclei and phospho-STAT3 (p-STAT3) in cytosols and nuclei.

Conclusions: This study indicates that curcumin ameliorates the depressed MFG-E8 expression and the attenuated phagocytic ability of EMF-exposed N9 cells, which is attributable to the inhibition of the pro-inflammatory response through the NF-KB and STAT3 pathways.

\footnotetext{
* Correspondence: xuesenyyy@gmail.com

${ }^{\dagger}$ Equal contributors

'Key Laboratory of Medical Protection for Electromagnetic Radiation Ministry

of Education, Third Military Medical University, 30 Gaotanyan Street,

Chongqing 400038, PR China

${ }^{2}$ Institute of Tropical Medicine, Third Military Medical University, Chongqing

400038, PR China

Full list of author information is available at the end of the article
} 


\section{Background}

The application of electromagnetic fields (EMFs) is ubiquitous in modern society [1]. Several epidemiological and experimental studies have shown that EMF exposure may have detrimental effects on cognitive function [2,3] and may increase the risk of neurological diseases, such as gliomas [4,5] and Alzheimer's disease [6,7]. EMF exposure has also been demonstrated to induce strong glial reactivity in different brain regions [8-10]. We previously observed that EMF exposure initiated the pro-inflammatory activation of microglial cells [11]. However, to our knowledge, there is no evidence for how EMF exposure induces depression of microglial phagocytosis.

The efficient removal of pathogens and cell debris by activated microglial cells is fundamental for central nervous system (CNS) development and homeostasis [12,13]. As an essential factor in the phagocytic process, milk-fat globule EGF factor-8 (MFG-E8), which has a phosphatidylserine (PS) binding domain, has been confirmed as a binding bridge between apoptotic cells and integrin $\alpha_{\mathrm{v}} \beta_{3}$ on the surface of phagocytes [14,15]. A strong pro-inflammatory response was found in MFG-E8 ${ }^{-/-}$mice [16]. Lipopolysaccharide (LPS), a potent stimulator of aberrant innate immune functions during inflammation, significantly decreases endogenous MFG-E8 levels in vivo and in vitro via the toll-like receptor 4 (TLR4) signaling pathway [17]. In contrast, the MFG-E8-mediated phagocytosis of apoptotic cells results in an inhibition of inflammation via the MAPK and nuclear factor- $\mathrm{B}$ (NF-kB) signaling pathways following the endotoxin response [18]. Thus, these findings indicate that the role of MFG-E8 in regulating the immune reaction of microglial phagocytosis and pro-inflammatory responses could depend on the types of stimulus.

During the clearance process, it has been confirmed that curcumin has an important role as an immunomodulator in inhibiting neurotoxicity and increasing the phagocytosis index $[19,20]$. Previous studies showed that curcumin attenuates microglial migration and triggers a phenotype with anti-inflammatory and neuroprotective properties [21]. The activation of microglial cells can be effectively inhibited by incubating them with curcumin, which decreases the production of $\mathrm{NO}$ [22] and proinflammatory cytokines, such as IL-1 $\beta$, IL- 6 and TNF- $\alpha$ [23]. Moreover, curcumin is able to suppress the inflammatory signaling of NF- $\mathrm{KB}$ and the signal transducers and activators of transcription (STATs) in LPS-stimulated microglial cells $[24,25]$. However, the exact molecular mechanisms underlying the salutary effect of curcumin on microglial phagocytosis in inflammation remain largely unknown.

N9 cells were used because they have been proven to mimic primary microglia $[26,27]$ and exhibit robust proinflammatory and phagocytic responses [28]. In this study, we tested the following questions. Does EMF exposure depress microglial phagocytosis during inflammation? If EMF depresses phagocytosis, does curcumin directly regulate the depression of microglial phagocytosis or through its anti-inflammatory effects? We demonstrated that the inhibition of microglial pro-inflammatory responses by curcumin restores MFG-E8-mediated phagocytosis after EMF exposure. These results may assist in the development of appropriate microglia-targeted interventions against neurological diseases.

\section{Methods}

\section{Cell culture and treatments}

N9 cells were cultured as described previously [26,27]. Briefly, cells were grown in Iscove's modified Dulbecco's medium (IMDM) (HyClone, Logan, UT, USA) with supplementary heat-inactivated fetal bovine serum (5\%) (HyClone), $2 \mathrm{mM}$ glutamine, $100 \mathrm{U} / \mathrm{ml}$ penicillin, $100 \mu \mathrm{g} / \mathrm{ml}$ streptomycin, and $50 \mu \mathrm{M} 2$-mercaptoethanol (SigmaAldrich, St Louis, MO, USA). Cells were seeded in $25 \mathrm{~cm}^{2}$ flasks $\left(1 \times 10^{6}\right.$ cells $\left./ \mathrm{ml}\right)$, six-well plates $\left(5 \times 10^{5}\right.$ cells/well $)$ or 24 -well plates $\left(1.5 \times 10^{5}\right.$ cells/well $)$ at $37^{\circ} \mathrm{C}$ in an incubator $\left(37^{\circ} \mathrm{C}, 5 \% \mathrm{CO}_{2}\right)$. After $24 \mathrm{~h}$ incubation, the medium was replaced with serum-free IMDM supplemented with the following agents for different experiments: a solvent control (tissue culture grade dimethylsulfoxide, SigmaAldrich), curcumin (5, 10 and $20 \mu \mathrm{M}$, Sigma-Aldrich), recombinant murine MFG-E8 (rmMFG-E8) (100, 500 and $1000 \mathrm{ng} / \mathrm{ml})$, anti-TLR4 (10 $\mu \mathrm{g} / \mathrm{ml})$ (MTS510, HyCult Biotechnology, Uden, Netherlands) and (+)-naloxone (1, 5 and $10 \mu \mathrm{M}$ ) (Sigma-Aldrich). After $1 \mathrm{~h}$ incubation, the cells were exposed to EMF for $20 \mathrm{~min}$ before they were subjected to staining or to extract proteins. To investigate inflammation in the inhibition of phagocytosis and to ensure the proper concentration for the blocking antibody was used in our experiments, the cells were treated with Escherichia coli LPS (200 ng/ml) (Sigma-Aldrich) as a positive control.

\section{Exposure system}

Household appliances, medical equipment and communication systems make extensive use of $2.45 \mathrm{GHz}$ pulsed microwaves [11]. Cells were exposed to a pulsed EMF in an anechoic chamber. The ambient air temperature inside the anechoic chamber was $25^{\circ} \mathrm{C}$ to $26^{\circ} \mathrm{C}$. Pulsed EMF pulses $(90 \mathrm{~mW})$ were delivered through a rectangular horn antenna connected horizontally to a handset (Philips PM 7320X, Sivers IMA, Kista, Sweden). The pulse duration was $2 \mu$ s and the pulse repetition rate was 500 pulses per second. The exposure was for 20 min to $2.45 \mathrm{GHz}$ pulsed microwaves at an average specific absorption rate of $6 \mathrm{~W} / \mathrm{kg}$. During the exposure, the handset was oriented vertically towards the cells at a distance of $90 \mathrm{~cm}$. Flasks and plates with cells were placed in the upper chamber of 
a Perspex ${ }^{\mathrm{Tm}}$ water bath $(24.5 \mathrm{~cm} \times 21 \mathrm{~cm})$ to maintain a temperature of $37^{\circ} \mathrm{C}$ during the EMF exposure. The temperature of the medium in the flasks in the upper chamber was maintained at $37^{\circ} \mathrm{C}$ by circulating heated water through a lower closed chamber. During the sham exposures, control cells experienced the same conditions but without EMF treatment.

\section{Flow cytometry}

Fluorescence-activated cell sorting (FACS) analysis quickly evaluated microglial activation by detecting CD11b expression. Briefly, N9 cells were washed three times in a flow buffer (PBS containing $0.1 \%(\mathrm{w} / \mathrm{v})$ sodium azide and $1 \%(w / v)$ BSA). The cells were then incubated with goat serum (Zhongshan Goldenbridge Biotechnology (ZsBio), Beijing, China) for $20 \mathrm{~min}$ at $4^{\circ} \mathrm{C}$ to block the non-specific binding to Fc receptors. Cells were then spun $(5,000 \mathrm{rpm}$, $5 \mathrm{~min}$ ) and washed three times in the flow buffer. Subsequently, the cells were incubated with the rat anti-mouse monoclonal antibody to CD11b (1:100) (AbD Serotec, Oxford, UK) or the rat IgG2b isotype control (1:100) (AbD Serotec) for $1 \mathrm{~h}$ at $4^{\circ} \mathrm{C}$. Goat anti-rat IgGDyLight ${ }^{\circledR} 549$ (1:200) (AbD Serotec) was used as a secondary antibody. Cells were resuspended in ice-cold flow buffer $(250 \mu \mathrm{l})$. Quantitative analysis was performed using a FACSCalibur system (BD Biosciences, San Jose, CA, USA).

\section{Immunofluorescent staining}

Our phagocytic model used N9 cells to engulf fluorescent bioparticles (see detailed description below). Round glass cover slips were placed in the well of 24-well plates before seeding N9 cells. After the 20 min EMF exposure, bioparticles $\left(5 \times 10^{6}\right.$ per well $)$ were added to all wells and incubated for different times. Bioparticles were added $1 \mathrm{~h}$ before the indicated time points that the cells were tested in the phagocytosis assay. Then the glass cover slips were carefully taken out of the wells at different times and rinsed twice in PBS. After being fixed and permeabilized, the cells were blocked with goat serum (ZsBio) for $20 \mathrm{~min}$ at room temperature and washed three times in PBS. The cells were incubated with the rat anti-mouse monoclonal antibody CD11b (1:100) $\left(\mathrm{AbD}\right.$ Serotec) at $37^{\circ} \mathrm{C}$ for $1 \mathrm{~h}$. After washing three times in PBS, the cells were incubated with the goat anti-rat Alexa Fluor ${ }^{\circledR} 488$ secondary antibody (1:200) (Molecular Probes, OR, USA) for $1 \mathrm{~h}$ at $37^{\circ} \mathrm{C}$ in the dark. The cover slips with cells were washed three times in PBS and mounted with an aqueous-based anti-fade mounting medium on glass slides. Images of stained cells were captured using a Leica TCS-SP5 confocal laser scanning microscope (Leica, Mannheim, Germany). The confocal images were acquired using Imaris software (version 7.6; Bitplane, Zurich, Switzerland).

\section{Phagocytosis assay}

We performed serial phagocytosis assays on 24-well plates to evaluate the effects of EMF exposure on the phagocytic actions of N9 cells. The appearance of PS on the cellular plasma membrane is used by various phagocytes to recognize apoptotic cells. Therefore, we used a PS-binding Alexa Fluor ${ }^{\circledR}$ 647-conjugated Annexin V bioparticles system to mimic phagocytosis. Briefly, a solution of chloroform and methanol (19:1) was used to make PS solution $(10 \mathrm{mg} / \mathrm{ml})$. A three fold amount (v/v) of Alexa Fluor $^{\circledR}$ 647-conjugated Annexin V bioparticles was used to dilute the PS solution; then another 300-fold amount of IMDM (v/v) was added to the mixed PS solution and incubated at $30^{\circ} \mathrm{C}$ for $30 \mathrm{~min}$. The solution was then sonicated three times for $10 \mathrm{~s}$ each at $10 \mathrm{kHz}$ and centrifuged at $500 \mathrm{rpm}$ for $10 \mathrm{~min}$. The bioparticles were added $1 \mathrm{~h}$ before the indicated time points that the cells were tested in the phagocytosis assay. Then, a washing step with cold serum-free medium was performed to interrupt any interaction between the phagocytosing microglia and the uningested bioparticles.

The phagocytic ability of N9 cells was evaluated using the fluorescence intensity of the engulfed bioparticles on a plate reader and fluorescence microscopy. The fluorescence plate reader assay was conducted as explained in a previous study [29]. Plates were read on a Tecan Infinite M200 plate reader at an excitation wavelength of $643 \mathrm{~nm}$ and an emission wavelength of $665 \mathrm{~nm}$. The fluorescence intensity of the bioparticles in the microscopy assay was calculated as described in previous studies [30-32]. Five replicates were used for each experimental condition. As a negative control, wells with and without cells were used to calculate the background fluorescence, which was then subtracted from the experimental wells. The autofluorescence properties of the negative controls were indistinguishable. The positive control was N9 cells treated with bioparticles alone.

\section{Enzyme-linked immunosorbent assay of TNF-a, IL- 6 and IL-1 $\beta$}

The secretion of TNF- $\alpha$, IL- 6 and IL- $1 \beta$ into the culture supernatant was measured using mouse ELISA kits (eBioscience, San Diego, CA, USA). Briefly, 96-well ELISA plates (NUNC MaxiSorp, eBioscience) were covered with the capture antibody in the coating buffer $(1: 250,100 \mu \mathrm{l} /$ well) overnight at $4^{\circ} \mathrm{C}$. The wells were washed five times with wash buffer (PBST: Phosphate-Buffered Saline with $0.05 \%$ of Tween-20) and blocked with assay diluent at room temperature for $1 \mathrm{~h}$. Culture media for the different conditions were added to the wells $(100 \mu \mathrm{l} /$ well $)$ and held at $4^{\circ} \mathrm{C}$ to maximize sensitivity. The next day, the medium was removed and the wells were washed three times in PBST. The detection antibody (1:250, $100 \mu \mathrm{l} /$ well) was added to the wells. After $1 \mathrm{~h}$ incubation and following 
three washes, the plates were incubated with avidin-HRP (1:250, $100 \mu \mathrm{l} /$ well) for $30 \mathrm{~min}$ at room temperature. Each plate was subsequently incubated with tetramethylbenzidine substrate solution for $15 \mathrm{~min}$. This reaction was stopped with $50 \mu \mathrm{l}$ of $2 \mathrm{~N} \mathrm{H}_{2} \mathrm{SO}_{4}$ stop solution. Absorbance values were measured at $450 \mathrm{~nm}$ using a microplate spectrophotometer.

\section{Nitric oxide determination in culture medium}

The production of NO metabolites (nitrates and nitrites) in the culture medium was quantified using a NO detection kit (Nanjing Jiancheng Bioengineering Institute, Nanjing, China). This method uses nitrate reductase to reduce $\mathrm{NO}^{3-}$ to $\mathrm{NO}^{2-}$ specifically, and the content of $\mathrm{NO}^{2-}$ was determined colorimetrically. Briefly, $100 \mu \mathrm{l}$ of medium was added to each well. Then, $50 \mu$ of nicotinamide adenine dinucleotide and nitrate reductase were added to each well. After $30 \mathrm{~min}$, Greiss reagents I and II (both $50 \mu \mathrm{l}$ ) were added and incubated for $10 \mathrm{~min}$ at room temperature. The optical density of each well was determined using a microplate reader with an emission wavelength at $540 \mathrm{~nm}$.

\section{Western blotting}

N9 cells were harvested from flasks and washed twice with ice-cold PBS. The cells were lysed in RIPA lysis buffer (Roche, Penzberg, Germany) containing protease and phosphatase inhibitors (Roche) for $30 \mathrm{~min}$ on ice. Lysates were centrifuged at $12,000 \mathrm{rpm}$ for $10 \mathrm{~min}$ at $4^{\circ} \mathrm{C}$. Some cells were lysed with the Proteo JET ${ }^{\mathrm{TM}}$ Cytoplasmic and Nuclear Protein Extraction Kit (MBI Fermentas, MD, USA) to extract nuclear proteins, or the Proteo JET ${ }^{\mathrm{TM}}$ Membrane Protein Extraction Kit (MBI Fermentas) to extract membrane proteins. The protein concentration was determined using the bicinchoninic acid method (Beyotime Biotech, Beijing, China). SDS-PAGE (10\%) was used to separate the proteins (whole proteins including MFG-E8, $50 \mu \mathrm{g}$; membrane proteins including $\alpha_{\mathrm{v}} \beta_{3}$, $50 \mu \mathrm{g}$; cytoplasmic proteins including pTyr705-STAT3 and STAT3, $50 \mu \mathrm{g}$; or nuclear proteins including pTyr705STAT3 and NF-kB, $20 \mu \mathrm{g}$ ). Protein bands were transferred on to nitrocellulose membranes (Millipore, Bedford, MA, USA) at $4^{\circ} \mathrm{C}$. The membranes were blocked in PBS with $5 \%$ non-fat milk for $1 \mathrm{~h}$ and then incubated with primary antibodies recognizing MFG-E8 (1:500) (Santa-Cruz Biotechnology, Santa Cruz, CA, USA), $\alpha_{v} \beta_{3}$ integrin (1:1000) (Millipore), phospho-STAT3 (p-STAT3) (1:1000) (Cell Signaling Technology, Danvers, MA, USA), STAT3 (1:1000) (Cell Signaling Technology) and p65 NF-kB (1:1000) (Cell Signaling Technology) at $4^{\circ} \mathrm{C}$ overnight. Membranes were washed four times for $5 \mathrm{~min}$ each in tris-buffered saline plus $0.1 \%$ Tween-20 (TBST). A fluorescently labeled secondary antibody (IRDye ${ }^{\circledR}$ 800CW donkey anti-mouse IgG $(\mathrm{H}+\mathrm{L})$ and IRDye ${ }^{\circledR}$ 680RD donkey anti-rabbit IgG $(\mathrm{H}+$ L), (1:5000) (LI-COR, Lincoln, NE, USA) was used to bind the primary antibodies for $1 \mathrm{~h}$ at room temperature with gentle shaking in a dark area. After washing in TBST (four times, $5 \mathrm{~min}$ each), the protein bands were illuminated and quantified using an Odyssey infrared imaging system (LI-COR). Glyceraldehyde 3-phosphate dehydrogenase (GAPDH) (1:1000) (Cell Signaling Technology) and proliferating cell nuclear antigen (PCNA) (1:500) (Santa Cruz) were used as internal controls for cytoplasmic protein and nuclear protein, respectively. Protein bands were semiquantified by densitometric analysis using ImageJ 1.46.

\section{Statistical analysis}

Statistical analysis was performed using SPSS software. Each experiment was repeated a minimum of three times and the data expressed as means \pm SEM. Statistical differences between the groups were assessed by two-way ANOVA followed by Tukey's test. Statistical significance was established at $P<0.05$, unless otherwise indicated.

\section{Results}

\section{Alteration of phagocytic ability of N9 cells after EMF exposure}

EMF exposure dramatically enhanced the expression of CD11b but reduced the phagocytic ability of N9 cells. The expression of CD11b was measured using FACS analysis of the N9 cells cultured in different conditions (Figure 1A). The fluorescent light of the CD11b dye (FL2 channel) generates an electronic signal that can be recorded as high (FL2-H) for the intensity of the staining. The intensity of the staining calculated from FL2-H showed that CD11b expression was quite similar in N9 cells incubated with curcumin and the control group (about 3.8 and 3.9, respectively, Figure 1B). But at $12 \mathrm{~h}$ after EMF exposure the expression of CD11b was significantly enhanced (12.2) compared to the control $(P<0.05$, Figure 1B). Curcumin incubation can effectively neutralize the enhancement of CD11b expression (5.7) after EMF exposure of N9 cells, though the expression level was still higher than for the controls (Figure 1B).

The microscopy assay showed that the normalized phagocytic ratio was $112 \%$ at $3 \mathrm{~h}$ after EMF exposure, which was similar to that of the control (normalized to $100 \%$ ) (Figure 1C,D). The normalized ratio dramatically dropped to $37 \%$ at $12 \mathrm{~h}$ post EMF exposure compared to the control $(P<0.05$, Figure 1D). Using a fluorescence intensity assay of phagocytosis, we observed that each group of N9 cells ingested a different number of bioparticles. Compared to the phagocytic ratio in control cells, the ratio was slightly higher in cells at $1 \mathrm{~h}(105 \%)$ and $3 \mathrm{~h}$ (112\%) after EMF treatment (Figure 1D), but it decreased to $92 \%$ in cells after $6 \mathrm{~h}$ and was significantly reduced after $12 \mathrm{~h}(36 \%, P<0.05$, Figure $1 \mathrm{D})$. These results indicate that EMF may be a potential risk factor for impaired microglial phagocytosis. 

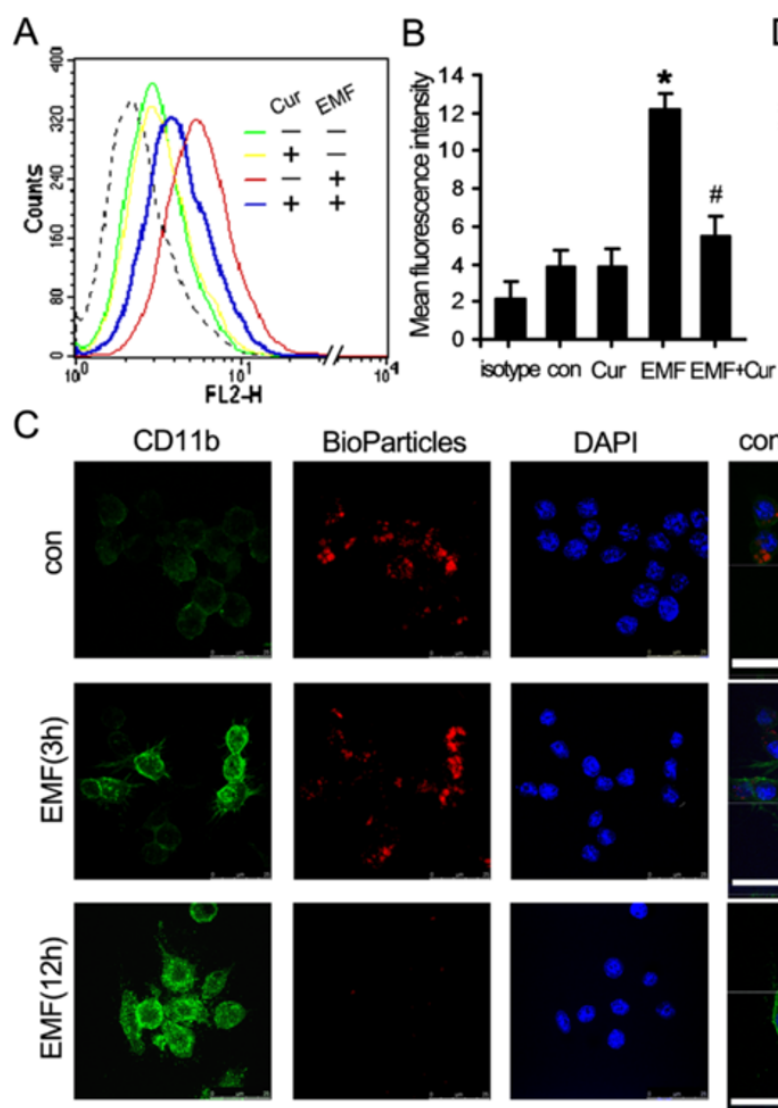

DAPI
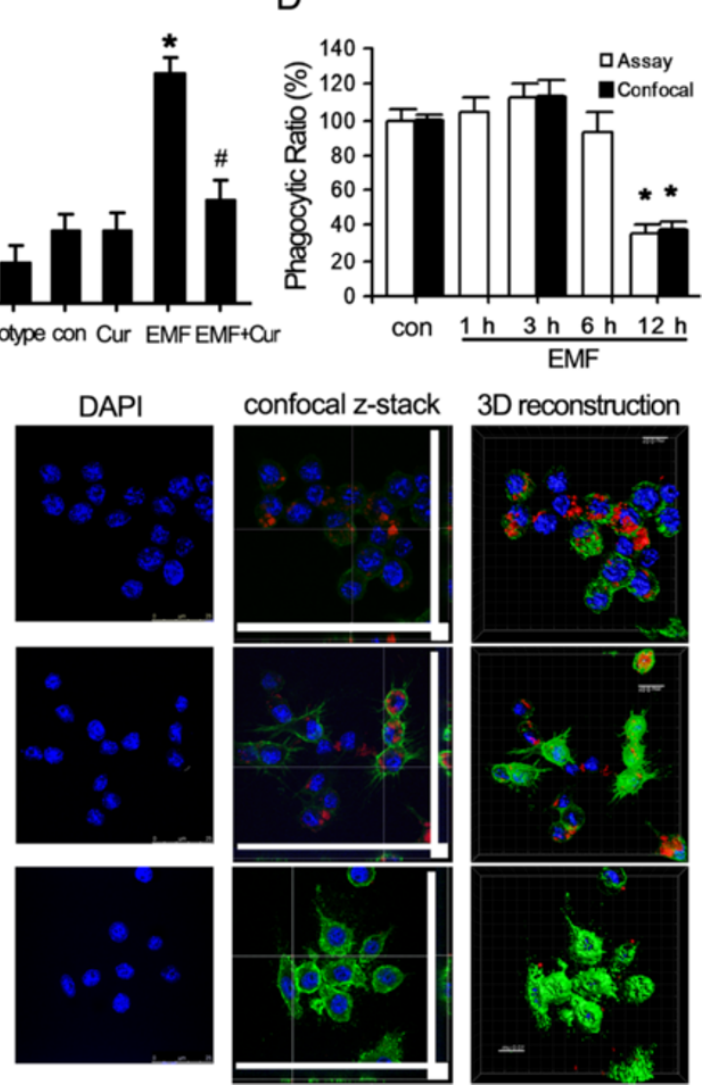

Figure 1 Reduction of phagocytic ability of $\mathbf{N} 9$ cells after EMF exposure. N9 cells were pretreated with $(+)$ or without $(-)$ curcumin $(20 \mu M)$ for $1 \mathrm{~h}$ and then exposed to $2.45 \mathrm{GHz}$ EMF (+) or sham exposed (-) for $20 \mathrm{~min}$. Untreated cultures were used as controls. (A) Representative flow cytometry histograms for CD11b expression at $12 \mathrm{~h}$ after EMF exposure. The fluorescence intensity in the FL2-H channel (X-axis) reflects CD11b content. (B) Average values of mean fluorescence intensity of CD1 1 b from three independent experiments normalized to the control. (C) Confocal and constructed 3D images of N9 cells used as controls, and $3 \mathrm{~h}$ and $12 \mathrm{~h}$ after EMF exposure. Scale bar: $25 \mu \mathrm{m}$. (D) Average fluorescence intensity of microspheres ingested per group estimated using the confocal images and multifunctional microplate reader. ${ }^{*} P<0.05$ vs the sham-exposed control group; ${ }^{P} P<0.05$ vs the EMFexposed group. con, control; Cur, curcumin; DAPI, 4',6-diamidino-2-phenylindole; EMF, electromagnetic field.

\section{Reduction of MFG-E8 expression is associated with phagocytic depression}

EMF exposure significantly depressed the expression of MFG-E8 in N9 cells. We found that the MFG-E8 levels in $\mathrm{N} 9$ cells from $0 \mathrm{~h}$ to $6 \mathrm{~h}$ after EMF treatment were quite similar to those of the controls. The normalized MFG-E8 expression in N9 cells increased about 0.4 fold compared to the internal control (GAPDH) (Figure 2A,B). However, MFG-E8 levels dramatically dropped to about 0.1 fold in N9 cells at $12 \mathrm{~h}$ after the EMF exposure (Figure 2A,B). Interestingly, the expression of $\alpha_{v} \beta_{3}$ integrins was not affected by EMF exposure and the normalized fold changes were quite stable (around 0.06 fold increase) (Figure 2A,B). These results indicated that MFG-E8 expression was significantly inhibited at $12 \mathrm{~h}$ after EMF exposure.

We tested whether the lower MFG-E8 expression depressed phagocytic ability. The normalized phagocytic ratio dropped to $36 \%$ for cells exposed to EMF compared with the sham-exposed controls (normalized to 100\%, Figure $2 \mathrm{C}, \mathrm{D})(P<0.05)$. When the culture medium was supplied with rmMFG-E8 (500 $\mathrm{ng} / \mathrm{ml})$, the ratio increased to $154 \%$ (Figure 2C,D), which was significantly higher than for the control $(P<0.05)$. We also found that the phagocytic ability increased with the concentration of rmMFG-E8 (100 ng/ml, $500 \mathrm{ng} / \mathrm{ml}$ and 1,000 ng/ml). The phagocytic ratios were $45 \%, 88 \%$ and $94 \%$ (Figure 2C,D), respectively.

All of these results demonstrate that EMF exposure can clearly reduce the phagocytic ability of N9 cells but addition of rmMFG-E8 can compensate for the reduction. Our observations confirm that rmMFGE8 can significantly enhance phagocytosis and restore phagocytic ability in EMF-exposed N9 cells compared to sham-exposed controls. These findings indicate that MFG-E8 plays an important role in phagocytosis. 
A

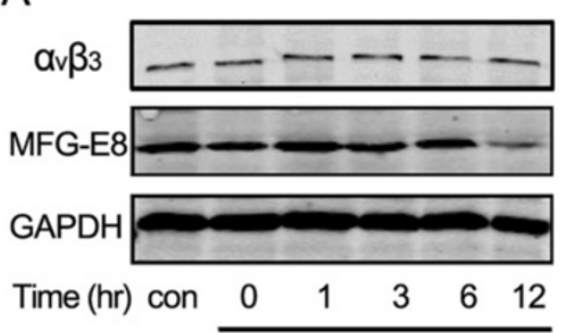

EMF
B

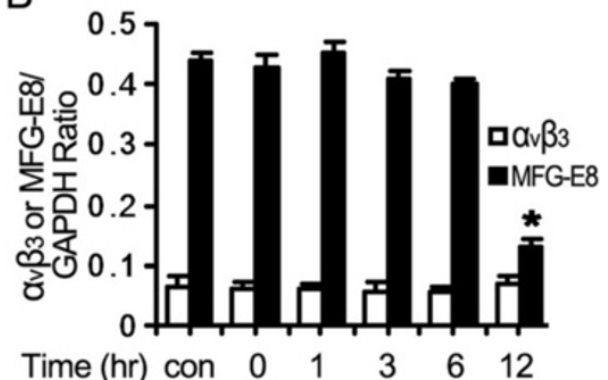

C
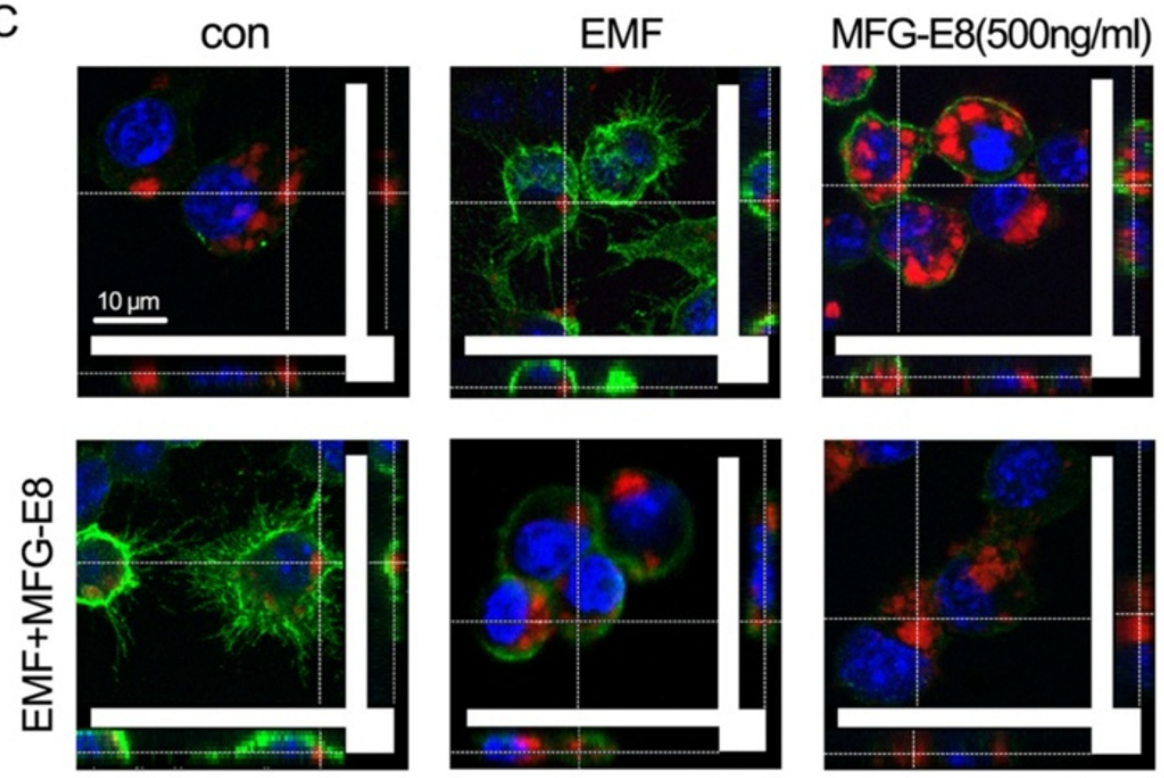

$100 \mathrm{ng} / \mathrm{ml}$

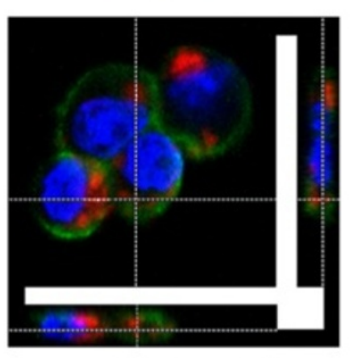

$500 \mathrm{ng} / \mathrm{ml}$

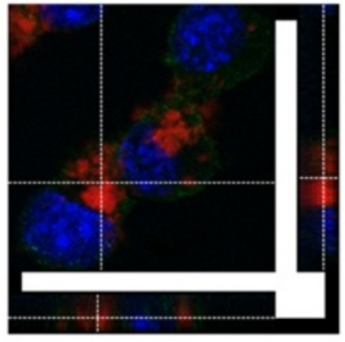

$1000 \mathrm{ng} / \mathrm{ml}$

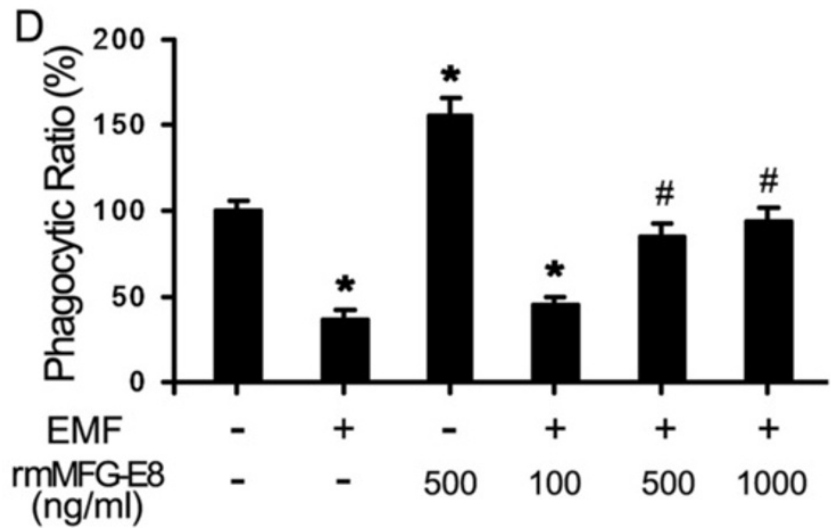

Figure 2 Improvement in phagocytic ability for EMF-exposed N9 cells with the addition of MFG-E8. N9 cells were pretreated with (+) or without (-) various concentrations of rmMFG-E8 (100, 500 and 1,000 ng/ml) for $1 \mathrm{~h}$ and then exposed to $2.45 \mathrm{GHz}$ EMF (+) or sham exposed (-) for 20 min. (A) Levels of MFG-E8 and $a_{v} \beta_{3}$ in total cell lysates and cellular membrane fractions were analyzed using Western blotting at the indicated times for EMF-stimulated N9 cells. Western blot results confirmed downregulation of MFG-E8, but not $\mathrm{a}_{\mathbf{v}} \beta_{3}$, at $12 \mathrm{~h}$ after EMF exposure. (B) The MFG-E8 and $a_{v} \beta_{3}$ /actin ratios were determined by densitometric analysis. (C) rmMFG-E8 pretreatment significantly improved the phagocytic ability of $\mathrm{N} 9$ cells at $12 \mathrm{~h}$ after EMF exposure. Scale bar: $10 \mu \mathrm{m}$. (D) Phagocytic ratios were calculated from (C). ${ }^{*} P<0.05$ vs the sham-exposed control group; ${ }^{P} P<0.05$ vs the EMF-exposed group. con, control; EMF, electromagnetic field; MFG-E8, milk-fat globule EGF factor-8; rmMFG-E8, recombinant murine MFG-E8. 


\section{Robust pro-inflammatory responses are linked to phagocytic depression}

Given the different changes of CD11b expression and phagocytic ability in N9 cells after EMF exposure, we measured levels of TNF- $\alpha$, IL-1 1 , IL- 6 and NO in cell culture medium supernatants at various times after EMF exposure. ELISA indicated that the secretion of TNF- $\alpha$, IL-1 $\beta$ and IL-6 was quite low in the sham-exposed control cells and the cells treated with curcumin at all time points (Figure $3 \mathrm{~A}, \mathrm{~B}, \mathrm{C}$ ). The expression of the three cytokines significantly increased in N9 cells after EMF exposure and reached a maximum at $12 \mathrm{~h}$ (Figure 3A,B,C). A similar pattern was observed when cells were treated with LPS as a positive control. Dramatically, the expression of the three cytokines dropped to the baseline level in EMF-exposed or LPS-treated N9 cells cultured with curcumin (Figure 3A,B,C). Similarly, no differences were found for the production of nitrite between control cells and curcumin-treated cells (Figure 3D). The levels of nitrite in the media significantly increased after EMF exposure or LPS treatment compared to the control (Figure 3D). The production of NO reduced when curcumin was used to incubate N9 cells after EMF exposure
(Figure 3D). In addition, levels of the microglial activation marker CD11b were significantly attenuated by curcumin preconditioning (Figure 1A,B).

The phagocytic ratio was quite similar in the controls and N9 cells incubated in curcumin but without EMF exposure (100\% vs 96\%). The normalized phagocytic ratio at $12 \mathrm{~h}$ was as low as $37 \%$ for N9 cells treated with EMF and 35\% for cells treated with LPS, which was significantly lower than the sham-exposed controls and curcumin-incubated cells $(P<0.05$, Figure $4 \mathrm{~A}, \mathrm{~B})$. Clearly, at $12 \mathrm{~h}$ the phagocytic ratio had improved from $6 \%$ to $43 \%$ in the EMF-exposed N9 cells supplied with curcumin compared to EMF-treated cells (Figure 4A,B). There was a dose-dependent change in phagocytic ability for N9 cells incubated with curcumin after EMF exposure (Figure 4A,B). These results suggest that the inhibition of microglial pro-inflammatory activation improves the phagocytic ability of N9 cells.

\section{TLR4 is not involved in chilling the pro-inflammatory} response and the amelioration of phagocytosis by curcumin Curcumin alone did not increase the phagocytic ability (Figure 4A,B) or the expression of MFG-E8 (Figure 5A)
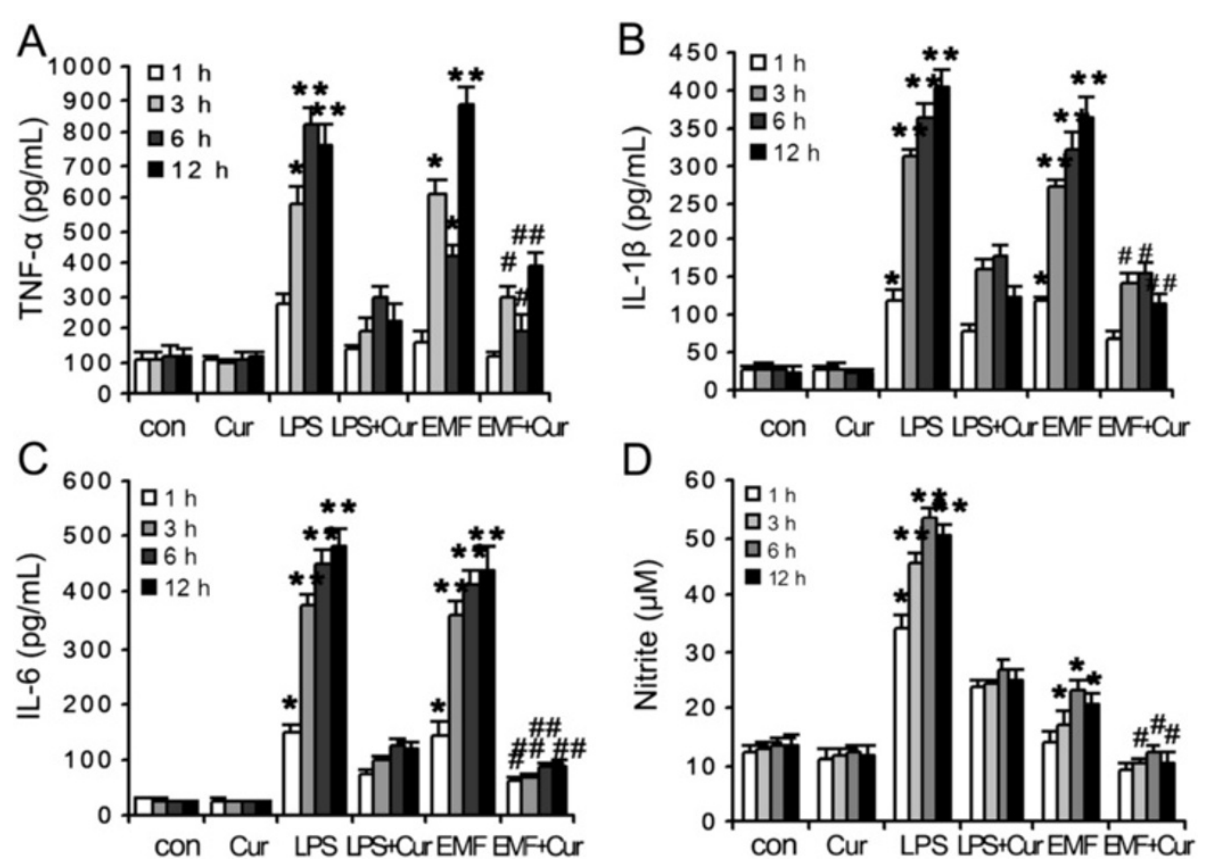

Figure 3 Inhibition by curcumin of TNF- $\mathbf{a}$, IL-1 $\mathbf{\beta}$, IL-6, and NO in EMF-exposed N9 cells. N9 cells were pretreated with (+) or without (-) $20 \mu \mathrm{M}$ curcumin for $1 \mathrm{~h}$, and then stimulated with $200 \mathrm{ng} / \mathrm{ml}$ LPS or a 20-min EMF exposure for the indicated times. Levels for each sample were normalized compared to total protein in cell lysates. The concentrations of TNF- $a(\mathbf{A}), I L-1 \beta$ (B) and IL-6 (C) in the medium were determined by ELISA after the cells were treated at the indicated times. (D) The amount of nitrite was determined by the Griess reaction. EMF exposure and LPS stimulation significantly increased the secretion of TNF-a, IL-1 $\mathrm{\beta}$ and IL-6 and the production of NO in a time-dependent manner from $1 \mathrm{~h}$ to $12 \mathrm{~h}$ for N9 cells exposed to EMF. Curcumin neutralized the effect in EMF-exposed N9 cells. ${ }^{*} P<0.05$, ${ }^{*} P<0.01$ vs the sham-exposed control group; ${ }^{\#} P<0.05,{ }^{\# \#} P<0.01$ vs the EMF-exposed group. con, control; Cur, curcumin; EMF, electromagnetic field; IL, interleukin; LPS, lipopolysaccharide; TNF-a, tumor necrosis factor $a$. 


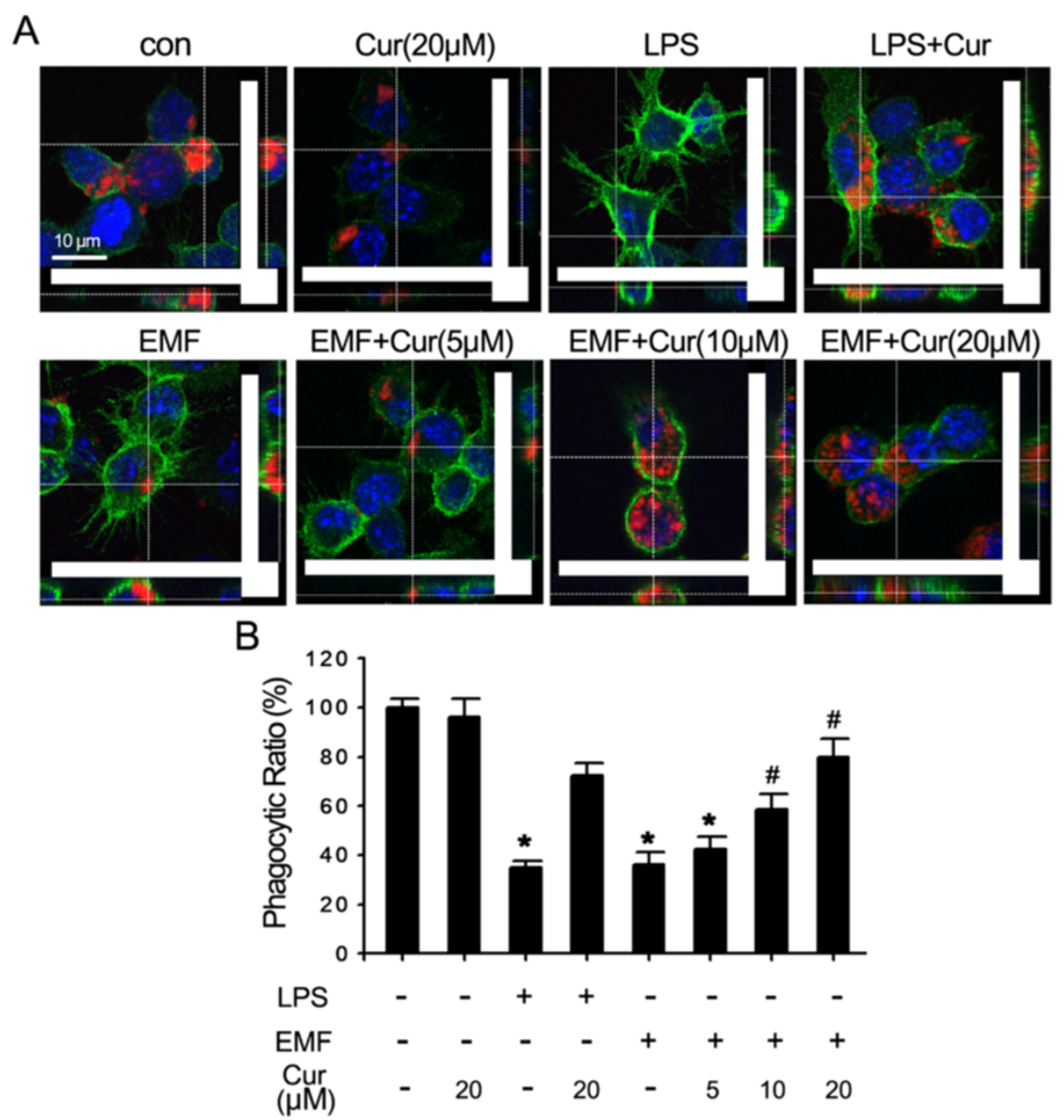

Figure 4 Amelioration by curcumin of phagocytic ability for EMF-exposed N9 cells. N9 cells were pretreated with (+) or without (-) various concentrations of curcumin (5, 10 and $20 \mu \mathrm{M}$ ) for $1 \mathrm{~h}$ and then exposed to $2.45 \mathrm{GHz}$ EMF (+) or sham exposed (-) for 20 min. (A) Curcumin pretreatment concomitantly improves microglial phagocytosis in a dose-dependent manner at $12 \mathrm{~h}$ after EMF exposure. No increase in microglial phagocytosis was detected upon curcumin preconditioning in the sham exposure group. Scale bar: $10 \mu \mathrm{m}$. (B) Quantification of the phagocytic ability of N9 cells was calculated from (A). The phagocytic ratio was significantly improved in the EMF-exposed or $200 \mathrm{ng} / \mathrm{ml}$ LPS-treated N9 cells incubated with $10 \mu \mathrm{M}$ and $20 \mu \mathrm{M}$ of curcumin. ${ }^{*} P<0.05$ vs the sham-exposed control group; ${ }^{\#} P<0.05$ vs the EMF-exposed group. con, control; Cur, curcumin; EMF, electromagnetic field; LPS, lipopolysaccharide.

for the sham exposure group. These results indicate that the improvement of microglial phagocytosis was not directly regulated by curcumin alone. The normalized fold change of protein expression showed that EMF exposure clearly inhibited the expression of MFG-E8 compared to the sham exposure controls ( 0.11 vs 0.43 , Figure $5 \mathrm{~A}, \mathrm{~B})$. An increasing trend of fold change was found for MFGE8 expression when the EMF-exposed N9 cells were incubated with curcumin (from 0.14 to 0.39, Figure 5A) or naloxone (another anti-inflammatory factor, from 0.14 to 0.22 , Figure $5 \mathrm{~B}$ ).

We also tested whether the restoration of MFG-E8mediated phagocytosis by curcumin was due to the regulation of TLR4. The expression of TLR4 remained at the basal level for each condition, including the curcumintreated group. The expression of TLR4 was not affected by the addition of curcumin or naloxone, which is a TLR4 inhibitor (Figure 5B). The normalized fold changes were quite similar in all groups (all around 0.50). However, in the TLR4 antibody blocking experiment, the antiTLR4 antibody did not improve the expression of MFGE8 (Figure 6C) or ameliorate the phagocytic ratio (Figure 6A,B) in N9 cells treated with EMF. As a positive control, LPS treatment significantly depressed microglial phagocytosis, and this was reversed by the anti-TLR4 antibody (Figure 6A,B). These findings show that the TLR4 pathway might not be involved in the curcumin-mediated improvement of defective phagocytosis. 

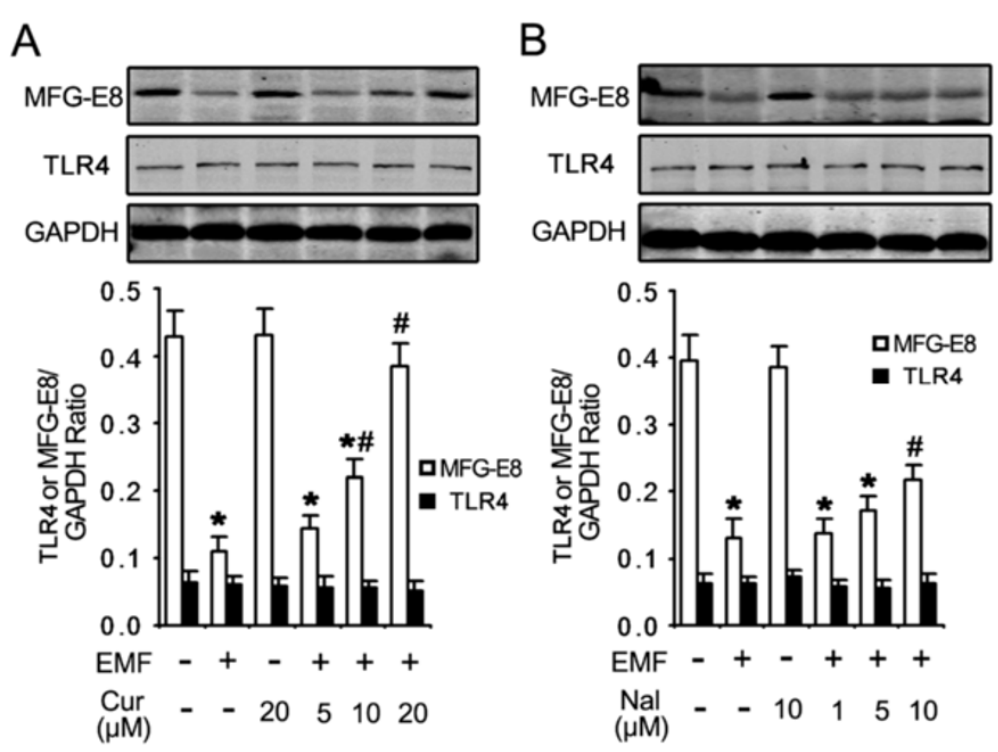

Figure 5 Restoration of MFG-E8 expression in EMF-exposed N9 cells incubated in curcumin and naloxone. N9 cells were pretreated with $(+)$ or without (-) various concentrations of curcumin $(5,10$ and $20 \mu \mathrm{M})$ or naloxone $(1,5$ and $10 \mu \mathrm{M})$ for $1 \mathrm{~h}$, and then exposed to $2.45 \mathrm{GHz}$ EMF $(+)$ or sham exposed (-) for $20 \mathrm{~min}$. GAPDH antibody was used as a control for equal protein loading. The pro-inflammatory inhibitors curcumin (A) and naloxone (B) significantly restored the expression of MFG-E8 in a dose-dependent manner at $12 \mathrm{~h}$ after EMF exposure but there was no change in TLR4 expression for all groups. Curcumin or naloxone pretreatment alone did not cause significant changes in MFG-E8 expression in the sham exposure group. ${ }^{*} P<0.05$ vs the sham-exposed control group; ${ }^{\#} P<0.05$ vs the EMF-exposed group. Cur, curcumin; EMF, electromagnetic field; MFG-E8, milk-fat globule EGF factor-8; Nal, naloxone; TLR4, toll-like receptor 4.

\section{The roles of NF-KB and STAT3 in the amelioration of phagocytic ability}

These findings above show that the improvement of phagocytic ability is not directly regulated by TLR4 through inhibition of the pro-inflammatory responses in N9 cells. Next we studied the anti-inflammatory role of curcumin and revealed that it inhibited the NF- $\mathrm{kB}$ and STAT3 pro-inflammatory pathways. Western blot analysis indicated that the addition of curcumin modified the expression of p-STAT3 but not STAT3 in EMFexposed N9 cells (Figure 7A). The normalized fold change $(0.40$ to 0.49$)$ of STAT3 was quite stable in the controls and other groups treated with EMF (Figure 7A). But an obvious increase of p-STAT3 expression was found in EMF-treated N9 cells (Figure 7A,B). After the addition of curcumin to the culture medium, the expression of p-STAT3 and NF- $k$ B was chilled down to the baseline level of around 0.30 and 0.46 fold compared to the controls for EMF-exposed N9 cells (Figure 7A,B). These results suggested that curcumin may ameliorate defective microglial phagocytosis via the inhibition of NF-kB activation and STAT3 phosphorylation, but not through alteration of TLR4 signaling.

\section{Discussion}

In the present study, we observed the alteration of the inflammatory response and phagocytosis for EMF-exposed N9 cells. We found significant decreases of phagocytic ability and MFG-E8 expression at $12 \mathrm{~h}$ in N9 cells after EMF exposure. The reduction of phagocytosis can be ameliorated in N9 cells incubated with rmMFG-E8. The pro-inflammatory response induced by the EMF exposure was significantly inhibited by curcumin. Interestingly, there was no detectable change in MFG-E8 expression when the TLR4 antibody was supplied to N9 cells, but it was altered by naloxone. Importantly, the STAT3 and NF$\kappa B$ pro-inflammatory pathways were significantly inhibited by curcumin too. This suggests that curcumin ameliorates EMF-mediated phagocytic depression in N9 cells via the immune regulation of MFG-E8 by the STAT3 and NF- $\mathrm{kB}$ pathways.

The primary effects of microglial activation in response to injury and stimuli are the pro-inflammatory and phagocytic responses. It has been reported that pro-inflammatory cytokines act selectively to regulate the different types of microglial phagocytosis [33]. Our results reveal that high levels of pro-inflammatory cytokines were released at $12 \mathrm{~h}$ after EMF exposure and this was accompanied by impaired microglial phagocytosis. In the unconjugated bilirubin activated microglial cell model, phagocytosis was similarly downregulated for a certain time period, while considerable amounts of pro-inflammatory cytokines were released [34]. Inflammation-induced aberrant innate immune functions can be prevented by the inhibition of inflammatory processes $[17,18,35,36]$. As our results demonstrate, inhibition of the EMF-induced pro-inflammatory response 

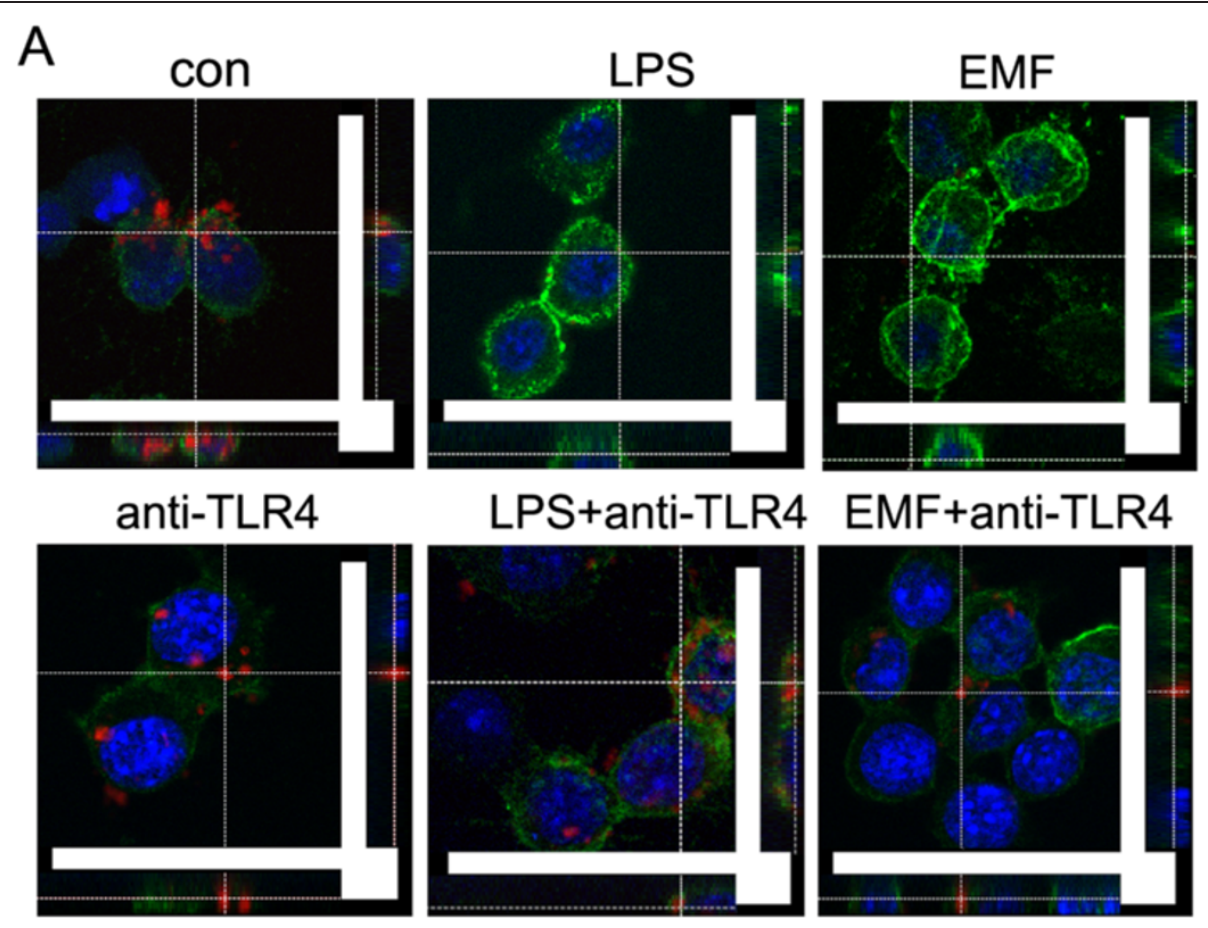

B
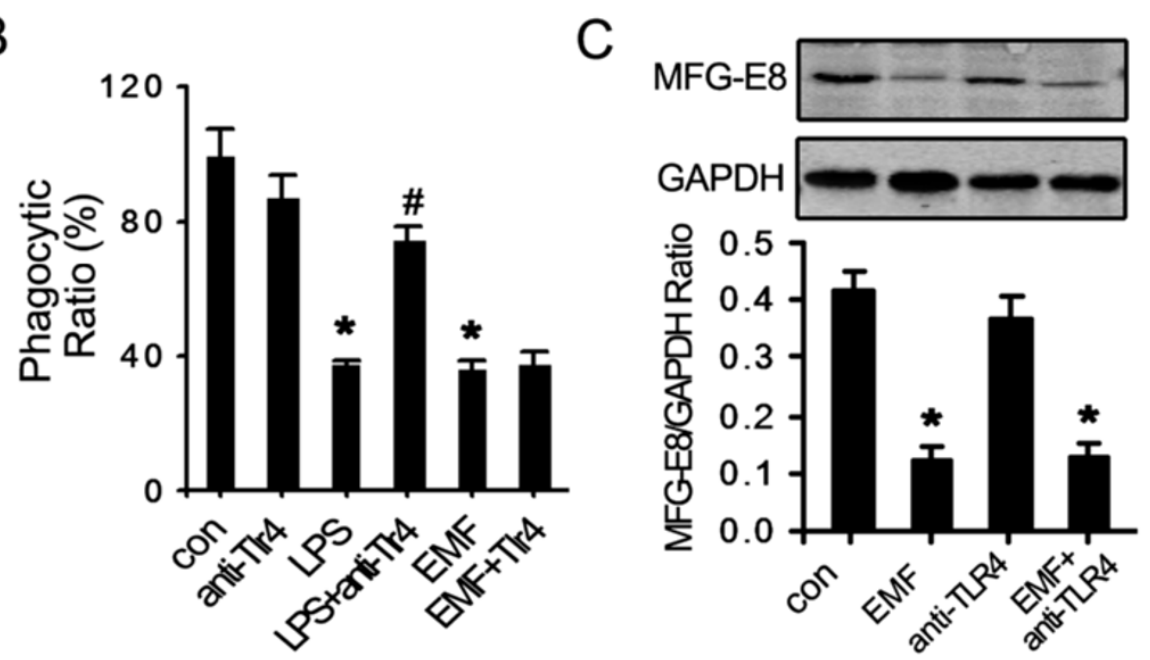

Figure 6 There was no change in the phagocytic ability of EMF-exposed N9 cells incubated in anti-TLR4 antibody. Experiments were performed at $12 \mathrm{~h}$ after EMF exposure or $200 \mathrm{ng} / \mathrm{ml}$ LPS treatment as described above. (A,B) Anti-TLR4 antibody (10 $\mu \mathrm{g} / \mathrm{ml})$ pretreatment had no effect on microglial phagocytosis. As a positive control, anti-TLR4 antibody prevented LPS-induced depression of microglial phagocytosis. Scale bar: $10 \mu \mathrm{m}$. (C) No significant changes in MFG-E8 expression were detected upon anti-TLR4 antibody preconditioning. ${ }^{*} P<0.05$ vs the sham-exposed control group; ${ }^{~} P<0.05$ vs the EMF-exposed group. con, control; EMF, electromagnetic field; LPS, lipopolysaccharide; MFG-E8, milk-fat globule EGF factor-8; TLR4, toll-like receptor 4 .

using curcumin restored the phagocytic functions of N9 cells. But no increase in phagocytic ability was detected in the control groups after addition of curcumin. Thus, the pro-inflammatory response may be associated with the downregulation of microglial phagocytosis in EMF-treated N9 cells.

EMF exposure can decrease microglial phagocytosis due to downregulated MFG-E8 expression in N9 cells. It has been well known that microglial cells phagocytose apoptotic cells through a process of migration, disfiguration and recognition [37,38]. The recognition of apoptotic cells is mediated by some specific receptors, such as the PS receptor [39] and $\alpha_{v} \beta_{3}$ [15]. The soluble PS-binding protein MFG-E8 is required for the recognition and phagocytosis of PS-exposing cells $[14,15,40]$. MFG-E8 deficiency is accompanied by the induction of pro-inflammatory cytokines and the impaired uptake of apoptotic cells in several inflammatory diseases, including systemic lupus 

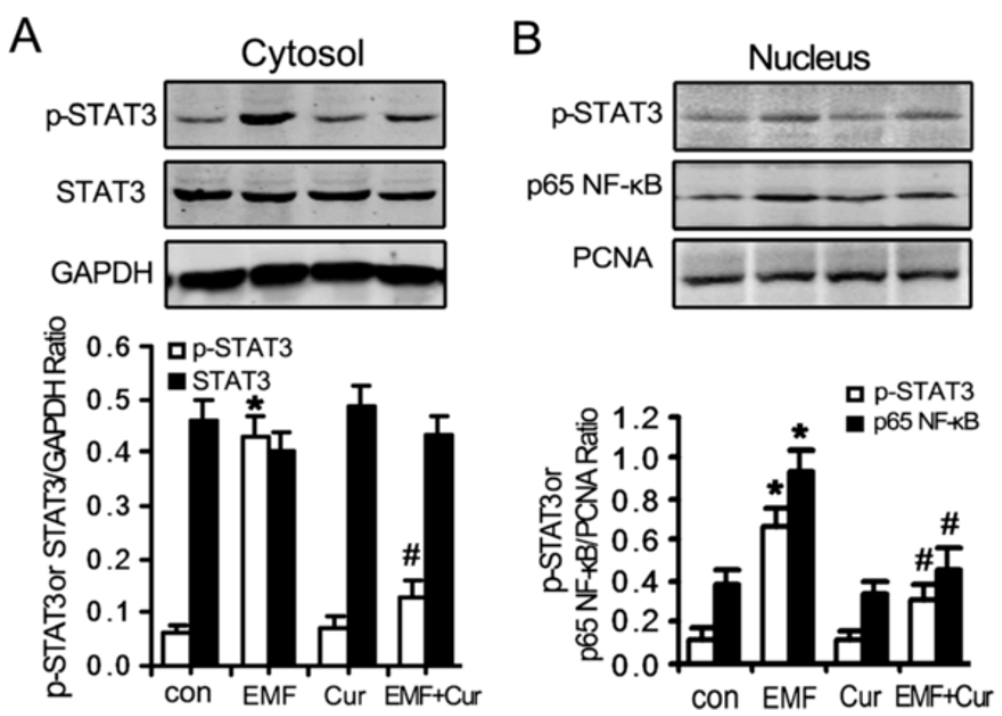

Figure $\mathbf{7}$ Involvement of NF-KB and STAT3 signaling in EMF-exposed $\mathbf{N} 9$ cells incubated in curcumin. N9 cells were pretreated with (+) or without (-) curcumin $(20 \mu \mathrm{M})$ for $1 \mathrm{~h}$, and then exposed to $2.45 \mathrm{GHz}$ EMF (+) or sham exposed (-) for $20 \mathrm{~min}$. Untreated cultures were used as a control. Curcumin pretreatment before EMF exposure significantly inhibits the STAT3 (A) and NF-KB (B) pro-inflammatory pathways. The nuclear extracts were prepared for Western blot analysis using antibodies against p65 NF-kB or PCNA (used as a loading control). ${ }^{*} P<0.05$ vs the sham-exposed control group; ${ }^{*} P<0.05$ vs the EMF-exposed group. con, control; Cur, curcumin; EMF, electromagnetic field; NF-kB, nuclear factor-kB; PCNA, proliferating cell nuclear antigen; p-STAT3, phospho-STAT3; STAT, signal transducer and activator of transcription.

erythematosus [16], sepsis [41] and atherosclerosis [42]. In our study, microglial phagocytosis was decreased in a proinflammatory environment at $12 \mathrm{~h}$ after EMF exposure, with a parallel decrease in MFG-E8 expression. But the supply of rmMFG-E8 significantly restored microglial phagocytosis. These results suggest that a failure to remove the dying cells dues to a decrease in MFG-E8 expression induced by the pro-inflammatory response. Thus, the proinflammatory response appears to cause the non-redundant immune suppression of MFG-E8 expression and microglial phagocytosis after EMF exposure.

Theoretically, TLR-mediated responses can regulate the responses required to eliminate cell debris and promote repair efficiently. Animals that received a single microinjection of TLR2 or TLR4 ligands at the site of sciatic nerve lesions cleared the degenerating myelin faster and recovered earlier than saline-injected control rats [43]. Moreover, the expression of these innate immune receptors by microglia is a natural defense mechanism to prevent $\beta$-amyloid peptide accumulation in the CNS [44]. It is recognized that downregulation of MFG-E8 production during sepsis is primarily dependent on activation of the LPS-CD14-TLR4 pathway, and that phagocytosis of apoptotic cells is associated with the TLR4-MFG-E8 pathway $[17,45]$. However, in our study TLR4 expression was not altered by curcumin or naloxone in EMF-exposed N9 cells. Our results also showed that the anti-TLR4 antibody had no effect on MFG-E8 expression and microglial phagocytosis in EMF-exposed N9 cells. Altogether, the regulation of MFG-E8 expression by the pro-inflammatory response under our experimental conditions was not mediated by TLR4. We propose that MFG-E8-dependent alterations in microglial phagocytosis are not due to the direct regulation of the TLR4 pathway, but rather to the indirect activity of downstream factors related to pro-inflammatory signaling at $12 \mathrm{~h}$ after EMF exposure.

Pro-inflammatory cytokines can promote self-propagating cycles of microglial activation by inducing the activation of NF- $\mathrm{kB}$ and STAT3, leading to cytokine generation, followed by further activation of NF- $\mathrm{kB}$ and STAT3 [46-48]. We reported a possible autocrine loop involving positive feedback between microglial activation and cytokine production [49]. Consistent with the inhibition of pro-inflammatory mediators by curcumin, we observed an anti-inflammatory role of curcumin via inhibition of the STAT3 and NF- $\kappa$ B pro-inflammatory pathways. Therefore, the NF- $\mathrm{kB}$ and STAT3 pathways are potentially involved in the anti-inflammatory therapeutic effects of curcumin in a variety of neuropathologies. In support of this, curcumin has been found to block the LPS-mediated induction of cyclooxygenase- 2 through inhibition of NF- $\kappa$ B and STAT3 [24,25]. Although the beneficial effects of curcumin can be observed under various experimental conditions, the effects of curcumin in microglial cells exposed to EMF remain to be fully elucidated. Further experiments are required to explore the detailed mechanisms underlying this process. Regardless of the mechanism, the data presented in this study may assist future studies that aim to determine the therapeutic potential of curcumin. 


\section{Conclusions}

Our data indicate that pro-inflammatory mediators released by EMF-activated microglia can regulate the expression of MFG-E8, thus decreasing MFG-E8-dependent microglial phagocytosis. The addition of curcumin prevented EMF-induced reductions in microglial phagocytosis and MFG-E8 expression via the inhibition of the proinflammatory response. Moreover, curcumin ameliorated phagocytic ability via the prevention of pro-inflammatory activity in an NF-кB- and STAT3-dependent manner without the involvement of TLR4. The modulatory effects of curcumin may have potential for drug discovery for neuroinflammatory disorders.

\section{Abbreviations}

BSA: bovine serum albumin; con: control; CNS: central nervous system; Cur: curcumin; ELISA: enzyme-linked immunosorbent assay; EMF: electromagnetic field; FACS: fluorescence-activated cell sorting; IL: interleukin; IMDM: Iscove's modified Dulbecco's medium;

LPS: lipopolysaccharide; MFG-E8: milk-fat globule EGF factor-8; NF-kB: nuclear factor-KB; NO: nitric oxide; PBS: phosphate-buffered saline; PCNA: proliferating cell nuclear antigen; PS: phosphatidylserine; p-STAT3: phospho-STAT3; rmMFG-E8: recombinant murine MFG-E8; STAT: signal transducer and activator of transcription; TBST: tris-buffered saline plus 0.1\% Tween-20; TLR: toll-like receptor; TNF-a: tumor necrosis factor a.

\section{Competing interests}

The authors declare that they have no competing interests.

\section{Authors' contributions}

This study is based on an original idea of XSY. GLH, YL and XSY wrote the manuscript. GLH and YL carried out the FACS and confocal double-label immunofluorescence assays. GLH, YL and CHC carried out the Western blotting assay. ML carried out some mediator assays. PG provided the EMF exposure system. ZPY analyzed the data. All authors have read and approved the final manuscript.

\section{Acknowledgements}

This work was supported by the National Natural Science Foundation of China (Nos 30970672, 30700931 and 81172647). N9 microglia were kind gifts from Dr Yun Bai, Third Military Medical University, China.

\section{Author details \\ ${ }^{1}$ Key Laboratory of Medical Protection for Electromagnetic Radiation Ministry of Education, Third Military Medical University, 30 Gaotanyan Street Chongqing 400038, PR China. ${ }^{2}$ Institute of Tropical Medicine, Third Military Medical University, Chongqing 400038, PR China. ${ }^{3}$ Southwest Eye Hospital, Southwest Hospital, Third Military Medical University, Chongqing 400038, PR China.}

Received: 1 July 2013 Accepted: 10 March 2014

Published: 19 March 2014

\section{References}

1. Ahlbom A, Bridges J, de Seze R, Hillert L, Juutilainen J, Mattsson MO, Neubauer G, Schuz J, Simko M, Bromen K: Possible effects of electromagnetic fields (EMF) on human health - opinion of the Scientific Committee on Emerging and Newly Identified Health Risks (SCENIHR). Toxicology 2008, 246:248-250.

2. Koivisto $M$, Krause $C M$, Revonsuo $A$, Laine $M$, Hämäläinen $H$ : The effects of electromagnetic field emitted by GSM phones on working memory. Neuroreport 2000, 11:1641-1643.

3. Nittby H, Grafström G, Tian DP, Malmgren L, Brun A, Persson BR, Salford LG, Eberhardt J: Cognitive impairment in rats after long-term exposure to GSM-900 mobile phone radiation. Bioelectromagnetics 2008, 29:219-232.

4. Schüz J, Böhler E, Berg G, Schlehofer B, Hettinger I, Schlaefer K, Wahrendorf J, Kunna-Grass K, Blettner M: Cellular phones, cordless phones, and the risk of glioma and meningioma (Interphone study group, Germany). Am J Epidemiol 2006, 163:512-520.

5. Hepworth SJ, Schoemaker MJ, Muir KR, Swerdlow AJ, van Tongeren MJ, McKinney PA: Mobile phone use and risk of glioma in adults: case-control study. BMJ 2006, 332:883-887.

6. Sobel E, Dunn M, Davanipour Z, Qian Z, Chui HC: Elevated risk of Alzheimer's disease among workers with likely electromagnetic field exposure. Am Acad Neurol 1996, 47:1477-1481.

7. Garcia AM, Sisternas A, Hoyos SP: Occupational exposure to extremely low frequency electric and magnetic fields and Alzheimer disease: a meta-analysis. Int J Epidemiol 2008, 37:329-340.

8. Mausset-Bonnefont $A L$, Hirbec $H$, Bonnefont $X$, Privat A, Vignon J, de Sèze R: Acute exposure to GSM 900-MHz electromagnetic fields induces glial reactivity and biochemical modifications in the rat brain. Neurobiol Dis 2004, 17:445-454.

9. Brillaud E, Piotrowski A, de Seze R: Effect of an acute $900 \mathrm{MHz}$ GSM exposure on glia in the rat brain: a time-dependent study. Toxicol 2007, 238:23-33.

10. Ammari M, Brillaud E, Gamez C, Lecomte A, Sakly M, Abdelmelek H, de Seze R: Effect of a chronic GSM $900 \mathrm{MHz}$ exposure on glia in the rat brain. Biomed Pharmacother 2008, 62:273-281.

11. Hao YT, Yang XS, Chen CH, Wang Y, Wang XB, Li MQ, Yu ZP: STAT3 signalling pathway is involved in the activation of microglia induced by $2.45 \mathrm{GHz}$ electromagnetic fields. Int J Radiat Biol 2010, 86:27-36.

12. Czeh M, Gressens P, Kaindl AM: The yin and yang of microglia. Dev Neurosci 2011, 33:199-209.

13. Napoli I, Neumann H: Microglial clearance function in health and disease. Neuroscience 2009, 158:1030-1038.

14. Li W: Eat-me signals: keys to molecular phagocyte biology and 'appetite' control. J Cell Physiol 2012, 227:1291-1297.

15. Fuller AD, Van Eldik LJ: MFG-E8 regulates microglial phagocytosis of apoptotic neurons. J Neuroimmune Pharmacol 2008, 3:246-256.

16. Hanayama R, Tanaka M, Miwa K, Shinohara A, Iwamatsu A, Nagata S: Identification of a factor that links apoptotic cells to phagocytes. Nature 2002, 417:182-187.

17. Komura H, Miksa M, Wu R, Goyert SM, Wang P: Milk fat globule epidermal growth factor-factor VIII is down-regulated in sepsis via the lipopolysaccharide-CD14 pathway. J Immunol 2009, 182:581-587.

18. Miksa M, Amin D, Wu R, Jacob A, Zhou M, Dong W, Yang WL, Ravikumar TS, Wang P: Maturati-induced down-regulation of MFG-E8 impairs apoptotic cell clearance and enhances endotoxin response. Int J Mol Med 2008, 22:743-748.

19. Cole GM, Morihara T, Lim GP, Yang F, Begum A, Frautschy SA: NSAID and antioxidant prevention of Alzheimer's disease: lessons from in vitro and animal models. Ann N Y Acad Sci 2004, 1035:68-84.

20. Zhang L, Fiala M, Cashman J, Sayre J, Espinosa A, Mahanian M, Zaghi J, Badmaev V, Graves MC, Bernard G, Rosenthal M: Curcuminoids enhance amyloid- $\beta$ uptake by macrophages of Alzheimer's disease patients. $J$ Alzheimers Dis 2006, 10:1-7.

21. Karlstetter M, Lippe E, Walczak Y, Moehle C, Aslanidis A, Mirza M, Langmann $\mathrm{T}$ : Curcumin is a potent modulator of microglial gene expression and migration. J Neuroinflammation 2011, 8:125.

22. Jung KK, Lee HS, Cho JY, Shin WC, Rhee MH, Kim TG, Kang JH, Kim SH, Hong S, Kang SY: Inhibitory effect of curcumin on nitric oxide production from lipopolysaccharide-activated primary microglia. Life Sci 2006, 79:2022-2031.

23. Jin $C Y$, Lee JD, Park C, Choi YH, Kim GY: Curcumin attenuates the release of pro-inflammatory cytokines in lipopolysaccharide-stimulated BV2 microglia. Acta Pharmacol Sin 2007, 28:1645-1651.

24. Kim HY, Park EJ, Joe EH, Jou I: Curcumin suppresses Janus kinase-STAT inflammatory signaling through activation of Src homology 2 domain-containing tyrosine phosphatase 2 in brain microglia. J Immunol 2003, 171:6072-6079.

25. Kang G, Kong PJ, Yuh YJ, Lim SY, Yim SV, Chun W, Kim SS: Curcumin suppresses lipopolysaccharide-induced cyclooxygenase-2 expression by inhibiting activator protein 1 and nuclear factor kappaB bindings in BV2 microglial cells. J Pharmacol Sci 2004, 94:325-328.

26. Righi M, Mori L, De Libero G, Sironi M, Biondi A, Mantovani A, Donini SD, Ricciardi-Castagnoli P: Monokine production by microglial cell clones. Eur J Immunol 1989, 19:1443-1448.

27. Corradin SB, Mauël J, Donini SD, Quattrocchi E, Ricciardi-Castagnoli P: Inducible nitric oxide synthase activity of cloned murine microglial cells. Glia 1993, 7:255-262. 
28. Bruce-Keller AJ, Keeling JL, Keller JN, Huang FF, Camondola S, Mattson MP: Antiinflammatory effects of estrogen on microglial activation. Endocrinology 2000, 141:3646-3656.

29. Uff CR, Pockley AG, Phillips RK: A rapid microplate-based fluorometric assay for phagocytosis. Immunol Invest 1993, 22:407-413.

30. Chan A, Magnus T, Gold R: Phagocytosis of apoptotic inflammatory cells by microglia and modulation by different cytokines: mechanism for removal of apoptotic cells in the inflamed nervous system. Glia 2001, 33:87-95.

31. Koenigsknecht J, Landreth G: Microglial phagocytosis of fibrillar $\beta$-amyloid through a $\beta 1$ integrin-dependent mechanism. J Neurosci 2004, 24:9838-9846.

32. Zizza P, lurisci C, Bonazzi M, Cossart P, Leslie CC, Corda D, Mariggiò S: Phospholipase A2IVa regulates phagocytosis independent of its enzymatic activity. J Biol Chem 2012, 287:16849-16859.

33. Koenigsknecht-Talboo J, Landreth GE: Microglial phagocytosis induced by fibrillar beta-amyloid and IgGs are differentially regulated by proinflammatory cytokines. J Neurosci 2005, 25:8240-8249.

34. Silva SL, Vaz AR, Barateiro A, Falcão AS, Fernandes A, Brito MA, Silva RF Brites D: Features of bilirubin-induced reactive microglia: from phagocytosis to inflammation. Neurobiol Dis 2010, 40:663-675.

35. Kinsner A, Pilotto V, Deininger S, Brown GC, Coecke S, Hartung T, Bal-Price A: Inflammatory neurodegeneration induced by lipoteichoic acid from Staphylococcus aureusis mediated by glia activation, nitrosative and oxidative stress, and caspase activation. J Neurochem 2005, 95:1132-1143.

36. Lamkanfi M: Emerging inflammasome effector mechanisms. Nat Rev Immunol 2011, 11:213-220.

37. Voll RE, Herrmann M, Roth EA, Stach C, Kalden JR, Girkontaite I: Immunosuppressive effects of apoptotic cells. Nature 1997, 390:350-351.

38. Rizzi M, Perego C, Aliprandi M, Richichi C, Ravizza T, Colella D, Velískŏvá J, Moshé SL, De Simoni MG, Vezzani A: Glia activation and cytokine increase in rat hippocampus by kainic acid-induced status epilepticus during postnatal development. Neurobiol Dis 2003, 14:494-503.

39. Fadok VA, Bratton DL, Rose DM, Pearson A, Ezekewitz RA, Henson PM: A receptor for phosphatidylserine-specific clearance of apoptotic cells. Nature 2000, 405:85-90.

40. Raymond A, Ensslin MA, Shur BD: SED1/MFG-E8: a bi-motif protein that orchestrates diverse cellular interactions. J Cell Biochem 2009, 106:957-966.

41. Wu R, Chaung WW, Zhou M, Ji Y, Dong W, Wang Z, Qiang X, Wang P: Milk fat globule EGF factor 8 attenuates sepsis-induced apoptosis and organ injury in alcohol-intoxicated rats. Alcohol Clin Exp Res 2010, 34:1625-1633.

42. Ait-Oufella H, Kinugawa K, Zoll J, Simon T, Boddaert J, Heeneman S, Blanc-Brude O, Barateau V, Potteaux S, Merval R, Esposito B, Teissier E, Daemen MJ, Lesèche G, Boulanger C, Tedgui A, Mallat Z: Lactadherin deficiency leads to apoptotic cell accumulation and accelerated atherosclerosis in mice. Circulation 2007, 115:2168-2177.

43. Boivin $A$, Pineau I, Barrette $B$, Filali $M$, Vallières $N$, Rivest $S$, Lacroix S: Toll-like receptor signaling is critical for Wallerian degeneration and functional recovery after peripheral nerve injury. J Neurosci 2007 27:12565-12576.

44. Tahara K, Kim HD, Jin JJ, Maxwell JA, Li L, Fukuchi K: Role of toll-like receptor signalling in A $\beta$ uptake and clearance. Brain 2006, 129:3006-3019.

45. Miksa M, Wu R, Dong W, Das P, Yang D, Wang P: Dendritic cell-derived exosomes containing milk fat globule epidermal growth factor-factor VIII attenuate proinflammatory responses in sepsis. Shock 2006, 25:586-593.

46. Mir M, Tolosa L, Asensio VJ, Lladó J, Olmos G: Complementary roles of tumor necrosis factor alpha and interferon gamma in inducible microglial nitric oxide generation. J Neuroimmunol 2008, 204:101-109.

47. Yu H, Pardoll D, Jove R: STATs in cancer inflammation and immunity: a leading role for STAT3. Nat Rev Cancer 2009, 9:798-809.

48. Smith JA, Das A, Ray SK, Banik NL: Role of pro-inflammatory cytokines released from microglia in neurodegenerative diseases. Brain Res Bull 2012, 87:10-20.

49. Yang XS, He GL, Hao YT, Chen CH, Li M, Wang Y, Zhang GB, Yu ZP: The role of the JAK2-STAT3 pathway in pro-inflammatory responses of EMF-stimulated N9 microglial cells. J Neuroinflammation 2010, 7:54.

doi:10.1186/1742-2094-11-49

Cite this article as: He et al:: The amelioration of phagocytic ability in microglial cells by curcumin through the inhibition of EMF-induced pro-inflammatory responses. Journal of Neuroinflammation 2014 11:49.

\section{Submit your next manuscript to BioMed Central and take full advantage of:}

- Convenient online submission

- Thorough peer review

- No space constraints or color figure charges

- Immediate publication on acceptance

- Inclusion in PubMed, CAS, Scopus and Google Scholar

- Research which is freely available for redistribution 